\title{
High-Performance Human Resource Practices and Team Job Satisfaction: Moderating Role of Team Citizenship Behaviors
}

\author{
Kaumudi Misra, Ph.D. \\ Assistant Professor, Department of Management \\ College of Business and Economics, \\ California State University East Bay \\ 25800 Carlos Bee Blvd,
}

Hayward, CA 94542, USA.

Received: April 16, 2018 Accepted: May 24, 2018 Online published: June 4, 2018

doi:10.5296/ijhrs.v8i3.13010～URL: https://doi.org/10.5296/ijhrs.v8i3.13010

\begin{abstract}
Strategic human resource management literature has highlighted the role of high performance work systems as a set of workplace practices that enhance employee productivity and organizational performance. While the high performance literature has been around for over two decades now, research in this area has been staggered, and inconclusive about the organizational variables that comprise high performance work practices, as well as the effects of these practices on organizational outcomes - especially attitudinal employee outcomes such as job satisfaction and commitment. By creating an environment of empowerment and teamwork, high performance work practices motivate employees to perform better. One of the ways in which these workplace practices achieve higher performance is by eliciting discretionary, or extra-role behaviors, from employees. Using foundational research from the high performance paradigm, this paper examines the effects of team-level strategic HR practices on job satisfaction. Analyses of data collected from 138 frontline teams in US Midwestern hospitals, show that while self-managed work teams and team communication result in higher job satisfaction for members, this effect is mitigated when team members display organizational citizenship behaviors. Theoretical and practical implications of findings are discussed.
\end{abstract}

Keywords: high performance work practices, human resource practices, self-managed teams, job satisfaction, organizational citizenship behavior 


\section{Introduction}

While the impact of high performance human resource practices on firm performance has been widely studied in different contexts, the implications of such practices for employees remain relatively unaddressed. By design, high performance work practices increase organizational and team performance by resulting in positive outcomes for employees at the workplace, and eliciting discretionary behaviors from them. Past research has consistently shown that high performance work practices lead to job satisfaction (Berg, 1999; Fabi, Lacoursière, and Raymond, 2015; García-Chas, Neira-Fontela, and Varela-Neira, 2016; Huang, Ahlstrom, Lee, Chen, and Hsieh, 2016), and reduce turnover (Huselid, 1995; Fabi et al., 2015; Sikora, Ferris, and Van Iddekinge, 2015) among employees. An additional outcome for employees when high performance HR practices are implemented is the exhibition of discretionary effort (Berg, Kalleberg, and Appelbaum, 2003; Elorza, Harris, Aritzeta, and Balluerka, 2016; Shin and Konrad, 2017), or citizenship behaviors (Sun, Aryee, and Law, 2007; Snape and Redman, 2010; Kehoe and Wright, 2013; Wang, Baba, Hackett, and Hong, 2016; Li and Yu, 2017).

On the other hand, some research in this area has also debated over questions related to whether high performance practices might push employees to work harder (e.g. Ramsay, Scholaris and Harley, 2000; White, Hill, McGovern, Mills, C., and Smeaton, 2003; Jensen, Patel, and Messersmith, 2013; Van De Voorde and Jensen, 2016). These scholars present a "dark side' high performance work practices, arguing that while the implementation of these practices may increase organizational performance, they do so at the cost of making employees work harder and reduce employees' job satisfaction.

An additional aspect of high performance human resource practices (henceforth high-performance HR practices), is teamwork. Research in the high-performance paradigm as well as the strategic HR literature has shown that self-managed work teams, problem solving teams, participation in decision making, training, and communication between team members enhance organizational and unit-level performance by eliciting the discretionary effort of team members (Appelbaum, Bailey, Berg and Kalleberg, 2000; MacDuffie, 2005; Collins and Smith, 2006; Kehoe and Wright, 2013; Elorza et al., 2016; Shin and Konrad, 2017). One of the ways team members' exhibit discretionary behavior is by helping colleagues and going above and beyond their role requirements to engage in organizational citizenship behaviors (Organ, 1988; Wang et al., 2016; Li and Yu, 2017). While organizational citizenship behaviors are a positive outcome at the workplace, one could argue that these practices make people work harder and they are expected to put in more than what is required of their job. This could potentially result in negative outcomes for the individual employee in terms of longer working hours that have consequences for their satisfaction at work (White et al, 2003; Jensen et al., 2013; Van De Voorde and Jensen, 2016).

In this paper, I explore the effects of implementation of high performance practices and propose that, in order to make progress in the study of these practices and understand how to better implement them for efficient results, a more detailed examination of its impact on employees and teams is necessary. In an effort to do this, this study examines the relationship 


\section{Macrothink}

International Journal of Human Resource Studies

ISSN 2162-3058

2018, Vol. 8, No. 3

between high performance HR practices implemented for frontline teams, team-level job satisfaction, and organizational citizenship behaviors exhibited by team members, to unpack how the implementation of these workplace practices might play out for teams. It addresses questions such as: Are high-performance HR practices really beneficial to the employees working in these teams? What impact do these practices have on team members' satisfaction levels? Do they motivate team members to engage in citizenship behaviors, and what do these extra-role behaviors do for team members' job satisfaction?

Figure 1 is a graphical presentation of the research model proposed in this paper.

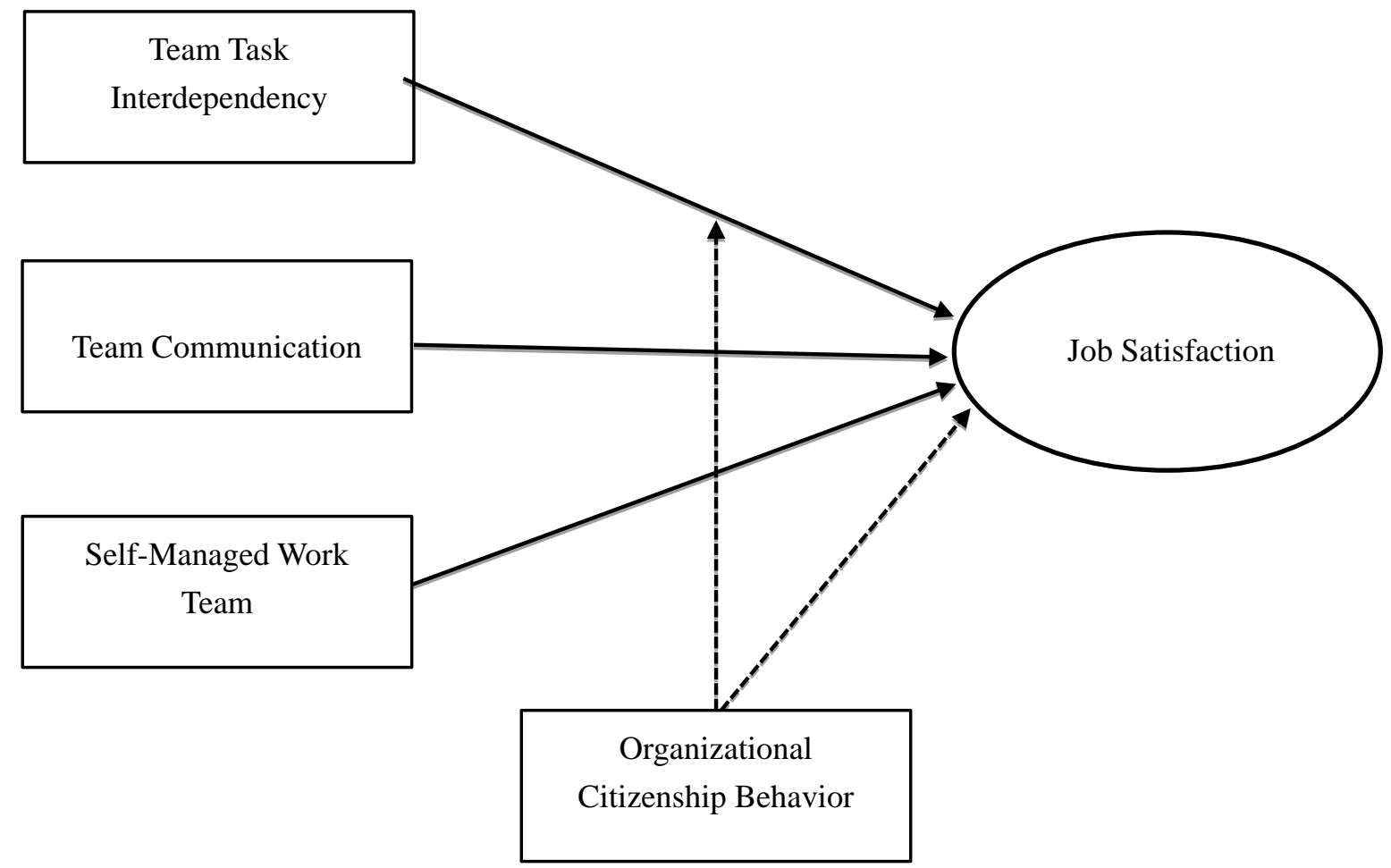

Figure 1. Conceptual Model

\section{Theoretical Background}

\subsection{High Performance Work Practices for Teams}

Numerous studies for more than two decades now, have established a positive link between the use of specific human resource practices and organizational performance (MacDuffie, 1995; Huselid, 1995; Ichniowski, Shaw, and Prennushi, 1997; Appelbaum et al, 2000; Jiang and Liu, 2015; Boxall, Guthrie, and Paauwe, 2016; Wood and Ogbonnaya, 2016). Human resource (HR) practices, such as team-based management, job rotation, gainsharing, and training have been shown to increase organizational and unit-level performance. A wide range of workplace practices comprising high performance HR practices, involve teamwork and coordination of work within teams (see Katzenbach and Smith, 2015). Total quality management, self-managing teams, problem-solving teams, teamwork training, cross training, pay for team-level performance, gainsharing plans, upward and downward communication and team autonomy are a few examples of team practices (e.g. Cappelli and Neumark, 2001; 
Berg et al., 2003; see also Posthuma, Campion, Masimova, and Campion, 2013 for a taxonomy of high performance practices).

As Berg (1999) writes: "Those practices that provide workers with the opportunity to intervene in the work process and to make decisions, that motivate workers to put forth discretionary effort, and that ensure that workers have the skills and ability to do their jobs are the foundation of a high performance work system" (1999: 113). A closer examination of the different practices named above shows that the use of self-managed teams, participation in coordinated team work teams, team communication, and the use of incentives are a common feature of the set of high performance work practices. Essentially, these work practices replace traditional forms of work, such as a Tayloristic approach to allow workers to have autonomy over their work tasks, to participate in self-directed teams, to be part of problem-solving and other offline teams and to regularly communicate with employees within and outside their work groups.

\subsection{High Performance Work Practices and Job Satisfaction}

Apart from organizational performance outcomes, scholars in the high-performance paradigm have also examined the impact of workplace practices on individual outcomes. Empirical evidence has shown that high-performance HR systems are associated with increased job satisfaction and employee engagement (for detailed reviews, see Macky and Boxall, 2007, 2008; Van De Voorde, Paauwe, and Van Veldhoven, 2012; Fabi et al., 2015; García-Chas, et al., 2016; Huang et al., 2016). Employees working as part of teams in which high performance work practices are implemented, experience higher levels of job satisfaction as they get more opportunities to participate in decision making and feel more involved at the workplace. The basic premise of high performance HR practices being employee motivation, these practices are designed to enhance employee involvement and satisfaction. For example, self-managed teams provide autonomy to team members in deciding how and when they do their work. Communication within and outside the team enables them to perform better and coordinated work results in feelings of enhanced cohesion among team members. These factors serve to enhance the satisfaction that 'high-performance team' members experience in doing their jobs. As such, I propose that high performance work practices such as self-managed teams, team communication and interdependent tasks, help increase the job satisfaction of team members in high performance work teams.

Hypothesis 1: Task Interdependency will have a positive effect on team job satisfaction.

Hypothesis 2: Team communication will have a positive effect on team job satisfaction.

Hypothesis 3: Self-managed Teams will have a positive effect on team job satisfaction.

\subsection{High Performance Work Practices and Organizational Citizenship Behavior}

A salient outcome of high performance work practices that has been agreed upon by researchers is that these practices elicit the discretionary effort among employees. High performance scholars suggest that some human resource systems result in enhanced organizational performance by making workers contribute their discretionary effort 
(MacDuffie, 1995; Appelbaum et al, 2000; Elorza, et al., 2016; Shin and Konrad, 2017). Discretionary effort is defined as "worker creativity and imagination...the intimate and often unconscious knowledge of the work process" (Appelbaum et al, 2000: 26) - the kind of effort that managers try so hard to get employees to elicit. Although discretionary effort has been shown to be the reason why high performance work practices enhance performance, such effort remains the "black box" of the high performance systems model and needs further exploration. I suggest that organizational citizenship behavior (OCB) is one form of discretionary effort that results from the implementation of high performance work practices in the workplace.

\subsubsection{Organizational Citizenship Behavior and Discretionary Effort: "Going the Extra Mile"}

Organizational scholars have given ample theoretical attention to work behavior that is beyond the reach of traditional job performance measures but is beneficial to long-term organizational success. Numerous terms have been used to describe such behavior at the workplace, including organizational citizenship behavior (Organ, 1988, 1990; Graham, 1991; Schnake, 1991; Van Dyne, Graham and Dienesch, 1994), prosocial organizational behavior (Brief and Motowidlo, 1986), extra-role behavior (Van Dyne and Cummings, 1990), organizational spontaneity (George and Brief, 1992) and even counter-role behavior (Staw and Boettger, 1990).

Organizational citizenship behaviors (OCB) are behaviors of a discretionary nature that are not part of employees' formal role requirements, but nevertheless contribute to the effective functioning of an organization. Such extra-role behavior has been defined as behavior that goes outside the requirements of the job to have a positive impact on organizational performance. It may consist of helping others or redesigning processes to be more efficient or deviating from standard operating procedures when necessary to serve a good customer and has been referred to as citizenship behavior (Organ, 1988; Van Dyne et al, 1994), prosocial behavior (Brief and Motowidlo, 1986), organizational spontaneity (George and Brief, 1992) and discretionary behavior (MacDuffie, 1995; Appelbaum et al., 2000).

Skilled and knowledgeable workers who are not motivated are unlikely to contribute any discretionary effort. Further, motivated workers who lack required skills or knowledge might contribute discretionary effort, but with little impact on organizational performance. Thus, worker motivation, skills and knowledge, and supportive organizational structures are the most important organizational determinants of discretionary effort, or organizational citizenship behavior. All of which are elements of high performance work practices. I use a social network perspective to argue that when networks develop within closely knit work teams such as high performance teams, members' likelihood to engage in citizenship behaviors and help each other is an inevitable outcome.

\subsection{Social Network Theory and High Performance Work Teams: Members' Citizenship Behaviors}

Social network theory proposes that the pattern of relations among a set of actors - whether individuals, groups, or organizations - explains outcomes over and above the attributes of 
either the individuals or the set (see Wasserman \& Faust, 1994; Scott, 2017). Moreover, according to the theory, individual-level outcomes are determined by the social structure, which includes an individual's immediate contacts with other organizational members.

Social networks are constructed from particular kinds of relationships (Granovetter, 1973; Scott, 2017; Burt, 2017), e.g. friendship networks or communication networks (Carter, DeChurch, Braun, and Contractor, 2015; Burt 2017). Friendship networks are established among members with psychosocial support for each other and are based on trust. Communication networks, on the other hand, comprise advice relations and other instrumental kinds of relationships within organizations. It is important to note that there will be some overlap between the friendship and communications networks that an individual belongs to. This paper proposes that individuals learn and retain their learning in teams through their embeddedness in both these types of networks. A social network comprises a set of organizational members and the set of ties that link them - ties indicating either friendship or communication relationships that these members engage themselves in. The embeddedness of individuals in a network is captured well by the "closeness" concept, implying ease of access to resources from other members in the network. An individual who is maximally close would have direct, unmediated relationships with all other members of the network.

For example, an individual who was part of a team formed for the accomplishment of a particular task develops his or her task-related learning by remaining a part of the friendship network formed in the team. He or she will also benefit from the communication network formed during the tenure of the team, and advice and help will become available from other team members as they form part of the individual's social network. The focal person's embeddedness in the team will determine the level of resources that he or she can access from other members.

Participation in a designated team may motivate employees to interact on a regular basis for the achievement of a particular task. Although a team is a formal workgroup, informal relationships are also likely to emerge from these interactions (Orbach, Demko, Doyle, Waber, and Pentland, 2015; Farmer, 2017). The informal social network thus formed consists of members with different skills who interrelate with one another periodically to accomplish subtasks of their main responsibility. I argue that individuals' involvement in friendship (informal) and communication (instrumental) networks that develop due to their participation in high performance work teams will result in helping behaviors among team members. Members' are encouraged to engage in citizenship behaviors as they feel they belong to a social network and are responsible for self-managing their team outcomes.

\subsubsection{Team Members' Citizenship Behaviors and Job Satisfaction}

Engagement in citizenship behaviors has a potential direct impact on the job satisfaction of team members, especially in high performance work teams. When employees self-manage their teams and experience high levels of autonomy as is inherent in high performance work practices, they feel motivated to exhibit citizenship behaviors. This will further serve to increase the satisfaction of team members' job satisfaction. Similarly, for interdependent tasks, citizenship behaviors will help enhance team members' satisfaction levels. A high level of 
communication amongst team members, while helpful for discretionary effort and performance outcomes, may reduce the satisfaction of team members. High performance work teams have the expectation of being able to have a certain level of autonomy in their work and hence enhanced team communication in addition to discretionary efforts or citizenship behaviors may distract them from their own team goals, causing reduced job satisfaction. Consequently, I propose that team members' organizational citizenship behavior (OCB) will moderate the relationship between self-managed teams, team communication and task interdependency, and team-level job satisfaction.

Hypothesis 4: Organizational citizenship behavior $(O C B)$ will have a positive effect on team job satisfaction.

Hypothesis 5: Organizational citizenship behavior (OCB) will moderate the relationship between task interdependency and job satisfaction of high performing teams, such that high $O C B$ will mitigate the positive effect of task interdependency and job satisfaction.

Hypothesis 6: Organizational citizenship behavior (OCB) will moderate the relationship between team communication and job satisfaction of high performing teams, such that high $O C B$ will mitigate the negative effect of communication and job satisfaction.

Hypothesis 7: Organizational citizenship behavior (OCB) will moderate the relationship between self-managed work and job satisfaction of high performing teams, such that high $O C B$ will mitigate the positive effect of self-managed and job satisfaction.

\section{Method}

\subsection{Data and Sample}

Data for this research was collected using telephone interviews with frontline employees in hospitals in the US Midwest region. The sample consisted of 138 teams from the nursing, housekeeping and food services departments (final response rate was 82\%). Respondents worked as part of frontline teams and were responsible for joint outcomes within their teams. Additionally, owing to the critical sector they worked in (i.e. hospitals), these frontline employees worked closely with each as well as with other teams to perform coordinated work. Respondents managed their own schedules and work outcomes within their team. As such, the sample was well suited for a study of self-managed work teams and citizenship behaviors amongst team members.

\subsection{Measures}

Job Satisfaction. Six items asked respondents how satisfied they were with different aspects of their job, such as overall job satisfaction, satisfaction with growth and development opportunity, satisfaction with their pay. Responses were gathered using a four-point Likert scale $(1=$ very satisfied, $2=$ satisfied, $3=$ dissatisfied, $4=$ very dissatisfied $) .(\alpha=0.78)$.

High Performance Work Practices. Scales were adapted from Berg, Kalleberg and Appelbaum (2003) to measure high performance work practices

Task Interdependency. Four items asked respondents to what extent their job required them to 
coordinate with other team members. Responses were gathered using a four-point Likert scale $(1=$ great extent, $2=$ some extent, $3=$ to a small extent, $4=$ not at all $)(\alpha=0.52)$.

Team Communication. Five items asked respondents how often they communicated with other team members, others outside of their team and other colleagues in the hospital. Responses were gathered using a six-point Likert scale $((1=$ several times a day, $2=$ once a day, $3=$ a couple of times a week, $4=$ once a week, $5=$ less than once a week, $6=$ rarely or never) $(\alpha=0.67)$.

Self-Managed Work Team. Five yes/no items asked team members to indicate if they participated in self-managed teams regarding different work-related issues $(\alpha=0.81)$.

Organizational Citizenship Behavior. Organizational Citizenship Behavior was measured based on the validated scale from Van Dyne et al. (1994). This measure was picked was owing to its concise set of items validated across a variety of samples across industry and job types. Eight items asked employees about their participation level in teams, and willing ness to help coworkers $(\alpha=0.80)$.

Demographic Control Variables. Analyses controlled for the education level of respondents, as education could have a significant impact on team members' self-management, or job satisfaction.

Scales were aggregated to the team level for analyses. Table 1 shows the descriptive and correlation statistics for all measures used in the analyses.

Table 1. Descriptive Statistics and Correlations

\begin{tabular}{|c|c|c|c|c|c|c|}
\hline & 1 & 2 & 3 & 4 & 5 & 6 \\
\hline 1. Team Task Interdependency & 1.00 & & & & & \\
\hline 2. Team Communication & $.17^{*}$ & 1.00 & & & & \\
\hline 3. Self-Managed Work Team & -.05 & -.17 & 1.00 & & & \\
\hline 4. Team Job Satisfaction & $.17^{*}$ & -.12 & -.15 & 1.00 & & \\
\hline 5. OCB & -.07 & .11 & .09 & .22 & 1.00 & \\
\hline 6. Education & $-.21^{*}$ & $-.22^{*}$ & -.06 & .12 & .09 & 1.00 \\
\hline Mean & 1.50 & 3.08 & 0.31 & 2.07 & 2.64 & 3.97 \\
\hline Std. Dev. & 0.40 & 0.93 & 0.24 & 0.38 & 0.82 & 0.96 \\
\hline$N$ & 136 & 133 & 127 & 136 & 63 & 135 \\
\hline
\end{tabular}

* Correlation is significant at the 0.05 level (2-tailed)

\subsection{Analyses}

Data were analyzed using hierarchical regression techniques to test for (1) the direct effect of self-managed teams, team communication and task interdependency on team members' job satisfaction; (2) the moderated effect of citizenship behavior on the relationships in (1). Table 2 shows the results based on the empirical model that was tested. Scale items were recoded as necessary and aggregated to the team-level. Hierarchical regressions were run on aggregated variables using IBM SPSS 24.0 software. All scale reliabilities were close to or higher than the 0.70 criteria (Nunnally, 1978). The only exception being task interdependency which had a scale reliability of 0.52 . However, it was retained for analyses to allow for parsimony of empirical models tested and for giving precedence to theoretical considerations, rather than 


\section{Macrothink}

International Journal of Human Resource Studies

ISSN 2162-3058 2018, Vol. 8, No. 3

using a data-driven approach.

\section{Results}

\subsection{Direct Effects}

Hypotheses H1 through H3 involve examining the direct effects of the three highperformance HR Practices (Task Interdependency, Team Communication, and Self-Managed work Team) on Team Job Satisfaction. Education level of team members was used as a control variable. Column 1 of Table 2 summarizes the results obtained, including model $\mathrm{R}^{2}$.

Table 2. Direct and Moderating Effects of High Performance HR Practices and Member OCB on Team Job Satisfaction

\begin{tabular}{|c|c|c|c|c|}
\hline & $\begin{array}{l}\text { (1) Team Job } \\
\text { Satisfaction }\end{array}$ & $\begin{array}{l}\text { (2) Team Job } \\
\text { Satisfaction }\end{array}$ & $\begin{array}{l}\text { (3) Team Job } \\
\text { Satisfaction }\end{array}$ & $\begin{array}{c}\text { (4) Team } \\
\text { Job } \\
\text { Satisfaction }\end{array}$ \\
\hline \multicolumn{5}{|l|}{ Independent Variables } \\
\hline \multirow{2}{*}{ Team Task Interdependency } & $0.20 *$ & $0.22 *$ & $0.22 *$ & 0.39 \\
\hline & $(0.12)$ & $(0.12)$ & $(0.12)$ & $(0.33)$ \\
\hline \multirow[t]{2}{*}{ Team Communication } & -0.06 & $-0.50 * *$ & -0.05 & $-0.61 * * *$ \\
\hline & $(0.06)$ & $(0.20)$ & $(0.05)$ & $(0.20)$ \\
\hline \multirow[t]{2}{*}{ Self-Managed Work Team } & $-0.39 *$ & $-0.48 * *$ & 1.04 & $1.59 *$ \\
\hline & $(0.22)$ & $(0.22)$ & $(0.86)$ & $(0.89)$ \\
\hline \multicolumn{5}{|l|}{ Moderator } \\
\hline \multirow[t]{2}{*}{$\begin{array}{l}\text { Team Members' } \\
\text { Organizational Citizenship } \\
\text { Behaviors (OCB) }\end{array}$} & $0.11 * *$ & $-0.41 *$ & $0.25 * *$ & -0.28 \\
\hline & $(0.05)$ & $(0.24)$ & $(0.10)$ & $(0.28)$ \\
\hline \multicolumn{5}{|l|}{ Interaction Variables } \\
\hline \multirow[t]{2}{*}{$\begin{array}{l}\text { Task Interdependency * } \\
\text { OCB }\end{array}$} & & & & -0.06 \\
\hline & & & & $(0.13)$ \\
\hline \multirow[t]{2}{*}{ Communication * OCB } & & $0.16 * *$ & & $0.21 * * *$ \\
\hline & & $(0.00)$ & & $(0.07)$ \\
\hline \multirow[t]{2}{*}{ Self-Managed Team * OCB } & & & $-0.50^{*}$ & $-0.72 * *$ \\
\hline & & & $(0.29)$ & $(0.30)$ \\
\hline \multicolumn{5}{|l|}{$\begin{array}{c}\text { Control } \\
\text { Variables }\end{array}$} \\
\hline \multirow[t]{2}{*}{ Education-level } & 0.02 & 0.002 & 0.03 & -0.001 \\
\hline & $(0.07)$ & $(0.03)$ & $(0.07)$ & $(0.07)$ \\
\hline \multirow[t]{2}{*}{ constant } & $1.71 * * *$ & $3.18 * * *$ & $1.23 * *$ & $2.72 * * *$ \\
\hline & $(0.46)$ & $(0.79)$ & $(0.53)$ & $(0.85)$ \\
\hline Model p-value & 0.080 & 0.022 & 0.047 & 0.009 \\
\hline$R^{2}$ & 0.16 & 0.23 & 0.20 & 0.31 \\
\hline
\end{tabular}

Note: Estimates are unstandardized coefficients from Hierarchical Linear Regression Analyses (using data aggregated to the team-level).

$* * \mathrm{p}<0.01 ; * \mathrm{p}<0.05$.

In support of $\mathrm{H} 1$, team task interdependency has a positive effect on team job satisfaction ( $\beta=$ $0.20, \mathrm{p}<0.10$ ), but contrary to $\mathrm{H} 2$, the effect of team communication on team job satisfaction is statistically insignificant. While $\mathrm{H} 3$ is supported, and the results show that 
self-management of work teams has a significant effect on team job satisfaction, contrary to the hypothesized direction of the relationship, it has a negative effect on job satisfaction of team members $(\beta=-0.39, p<0.10)$, This negative result may be because when teams are required to self-manage, they may have to exert extra effort and self-discipline themselves, which could possibly be a cause for low job satisfaction. Consistent with Hypothesis 4, team members' organizational citizenship behaviors (OCB) has a direct, positive relationship with the teams' job satisfaction $(\beta=0.11, \mathrm{p}<0.05)$. The model $\mathrm{R}^{2}$ is 0.16 .

\subsection{Moderation by $O C B$}

To test H-5 through H-7, I ran hierarchical regression models using a multiplicative index between the three independent variables and the moderator (OCB). Education was the control variable as before. Table 2 (Columns 2, 3 and 4) presents the results from moderation tests. Table 2 (Column 2) shows a positive moderation effect by OCB on the relationship between team communication and team job satisfaction $(\beta=0.16 ; p<0.05)$. Column 3 of Table 2 shows a significant negative interaction effect between self-managed work team with OCB and team members' job satisfaction, $(-\beta=0.50 ; \mathrm{p}<0.10)$. Column 4 in Table 2 shows results for a combined model including simultaneous moderation of OCB and team task interdependency, team communication and self-managed teams on team job satisfaction. The test of this parsimonious model reveals that consistent with the previous two models, team members' OCB moderates the relationship between team communication as well as self-managed work team and team job satisfaction. Together, the results in Table 2 provide support for H6 and H7. H5 was not supported. Figures 2 and 3 (corresponding to Table 2) are graphical representations of the moderating effects described here.

Figure 2 shows that team communication has a negative effect on team job satisfaction, meaning when team members have to communicate more within or outside the team to get their job done, their job satisfaction is low. However, this negative effect is mitigated at high levels of OCB versus low OCB. When team members exhibit citizenship behaviors to help each other out, the negative effects on their job satisfaction is lowered.

Figure 3 shows that the positive effect of self-managed work teams on team job satisfaction is higher for teams with low OCB. Conversely, the positive effect of self-managed work teams on job satisfaction is diminished at higher levels of OCB. This could be due to the fact that when teams self-manage, as well as have to engage in helping behaviors, they feel overworked and less satisfied with their jobs. 


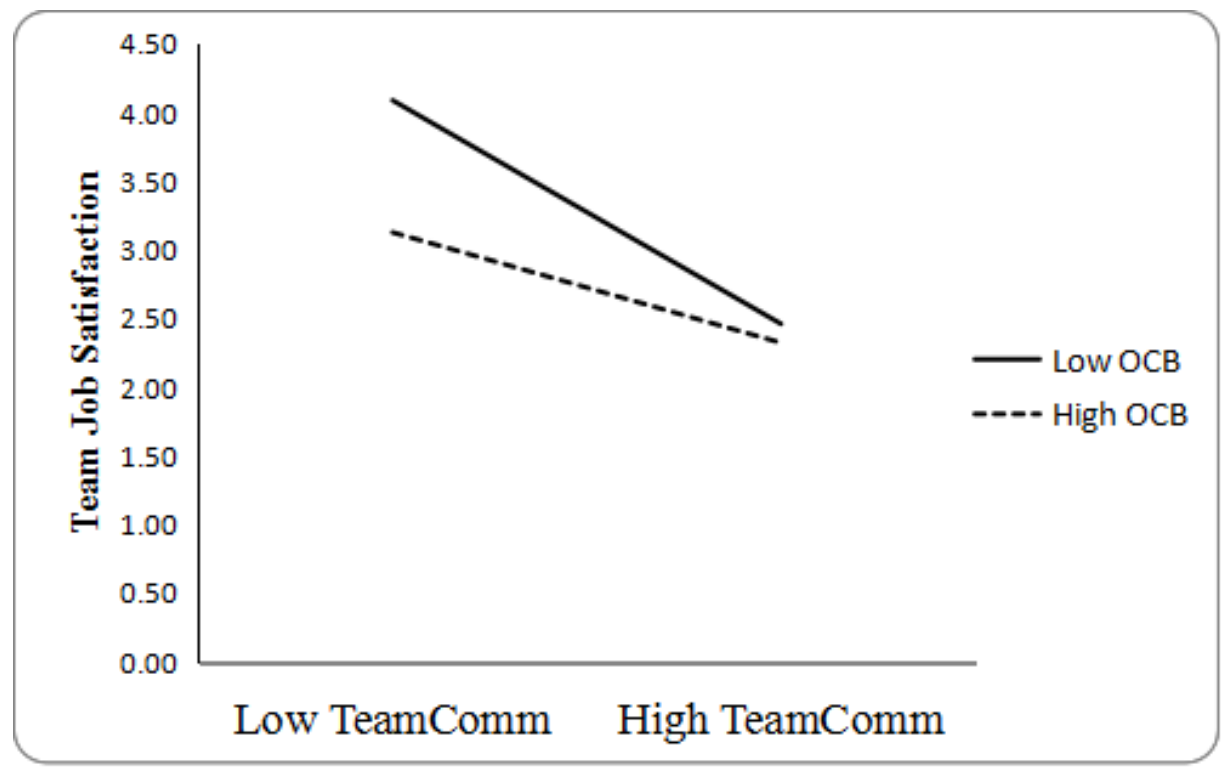

Figure 2. OCB dampens the negative relationship between Team Communication and Job Satisfaction

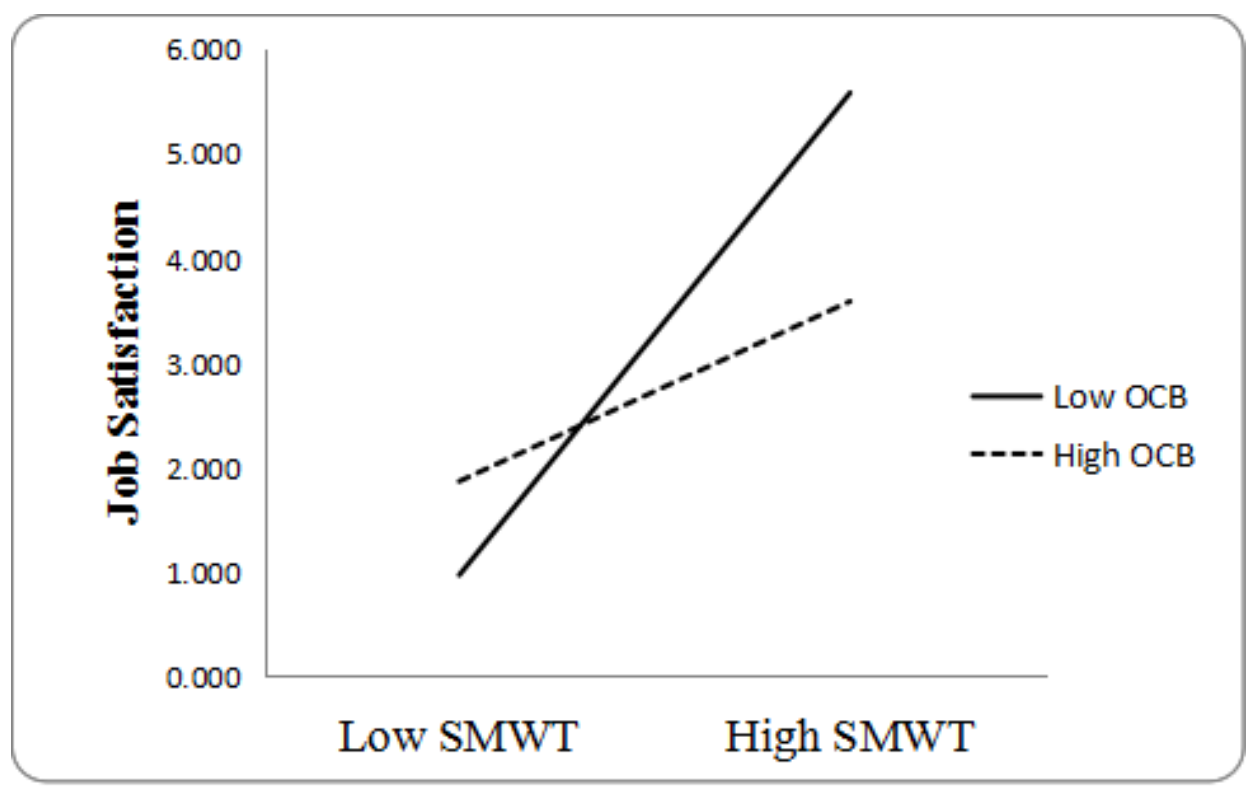

Figure 3. OCB dampens the positive relationship between Self-Managed Work Team and Job Satisfaction

\section{Discussion}

\subsection{Theoretical Implications}

This paper makes several contributions to existing literature on high performance HR practices. First, it adds to existing knowledge about outcomes for teams. Although the benefits of high performance human resource practices and organizing work in teams have been long established, research on the effects of high performance practices on team 
outcomes as well as employee attitudes has been limited. This paper sheds light on the same, and addresses the question as to how the coordinated work aspects of high performance teams (such as team communication, task interdependency and self-managed teams) affect team members' job satisfaction by enabling members' citizenship behaviors directed towards each other. The paper also explores the benefits of participation in high performance work teams for employees working as part of these teams, owing to the closely knit work outcomes and social networks that may develop among members. Coordinated work is especially relevant for frontline teams in a critical care sector such as hospitals. Because hospital employees have to work under strict timelines to provide care, as well as engage in highly coordinated work, this study provides helpful insights into the benefits of implementing high performance HR practices in these teams. Second, this study examines the impact of citizenship behaviors in high performing teams. It explores whether members engage in citizenship behaviors, and sheds light on the nuances of whether these behaviors actually benefit team members, and in what way. Third, this paper addresses the 'dark side' of high performance work practices to examine whether discretionary effort has a negative impact on the job satisfaction of employees that are part of high performance teams. One of the criticisms of research in the field of high performance work systems has been its lack of recognition potential for the negative impact of these practices on employees (Ramsay et al, 2001; Boxall and Macky, 2014). While high performance work practices may benefit employers as they increase organizational performance, they may do so at the cost of employee satisfaction as they could possibly push employees to work harder to raise productivity.

\subsection{Managerial Implications}

Results from this study will interest researchers and managers alike. By addressing an important question about the moderating effects of citizenship behavior on high performance work practices and team members' job satisfaction, this paper makes yet another case for teamwork and yields new insights into team learning and organizational knowledge transfer. It will be in the interest of managers to know how participation in a high-performance team can positively affect team members' job satisfaction. Individuals not only gain from their experience in teams but can also enhance their job satisfaction through the social networks developed from participation in teams. The benefits of team participation are indeed multifold and transgress the boundaries of informal groups as well as time. And by providing avenues for strong ties among members as they coordinate work closely, high performance HR practices will motivate team members to exhibit citizenship behaviors. Citizenship behaviors are an important aspect for organizational performance as well as team learning. Citizenship behaviors help mitigate the negative impact of high levels of communication required for coordinated work. Managers can use this information to design effective ways of implementing high performance human resource practices, to encourage social networks among members so that they engage in citizenship behaviors and help each other out with team tasks. Job satisfaction levels increases when team members exhibit citizenship behaviors, making the teams more effective. 


\subsection{Study Limitations ad Future Research}

This is a cross-sectional study using data collected from frontline hospital staff at one point in time. Further analyses need to be done for research rigor. A multilevel approach to testing the effects of high performance work practices, as experienced by individual employees and its effects on team outcomes, needs to be undertaken. Also, social networks and team OCB are group-level phenomenon and warrant multilevel analyses. Inspite of these limitations the findings from this study shed light on an important way in which high performance HR practices may help improve team outcomes and encourage citizenship behaviors among hospital employees - which is particularly important as healthcare requires highly coordinated work. Future research must look into other employee outcomes, such as turnover, job engagement, or work-family balance. Happy employees mean a better and more effective workplace. Citizenship behaviors could significantly help workplaces today, where more and more jobs require highly coordinate teamwork. Developing ways to enhance citizenship behaviors in the workplace need to be explored by human resource management scholars and practitioners alike.

\section{Acknowledgements}

The data used in this analysis was collected as part of a larger research project of U.S. hospitals involving Eileen Appelbaum, Peter Berg, Ann Frost, and Gil Preuss. All the researchers would like to thank the Russell Sage and Rockefeller foundations for their generous support of this research.

\section{References}

Appelbaum, E., Bailey, T., Berg, P., \& Kalleberg, A. L. (2000). Manufacturing Advantage: Why High Performance Work Systems Pay Off, Cornell University Press, 2000.

Berg, P. (1999). The effects of high performance work practices on job satisfaction in the United States steel industry. Relations industrielles/Industrial relations, 54(1), 111-135. https://doi.org/10.7202/051222ar

Berg, P., Kalleberg, A. L., \& Appelbaum, E. (2003). Balancing work and family: The role of high-commitment environments. Industrial Relations: A Journal of Economy and Society, 42(2), 168-188. https://doi.org/10.1111/1468-232X.00286

Boxall, P., \& Macky, K. (2014). High-involvement work processes, work intensification and employee well-being. Work, employment and society, 28(6), 963-984. https://doi.org/10.1177/0950017013512714

Boxall, P., Guthrie, J. P., \& Paauwe, J. (2016). Editorial introduction: Progressing our understanding of the mediating variables linking HRM, employee well-being and organisational performance. Human Resource Management Journal, 26(2), 103-111. https://doi.org/10.1111/1748-8583.12104

Brief, A., \& Motowidlo, S. (1986). Prosocial organizational behaviors, Academy of Management Review, 11, 710-725. https://doi.org/10.5465/amr.1986.4283909 
Burt, R. S. (2017). Structural holes versus network closure as social capital. In Social capital (pp. 31-56). Routledge.

Cappelli, P., \& David, N. (2001) "Do 'High-performance' work practices improve establishment-level outcomes?", Industrial and Labor Relations Review, 54(4), July 2001, pp. 737-775.

Carter, D. R., DeChurch, L. A., Braun, M. T., \& Contractor, N. S. (2015). Social network approaches to leadership: An integrative conceptual review. Journal of Applied Psychology, 100(3), 597. https://doi.org/10.1037/a0038922

Collins, C. J., \& Smith, K. G. (2006). Knowledge exchange and combination: The role of human resource practices in the performance of high-technology firms. Academy of management journal, 49(3), 544-560. https://doi.org/10.5465/amj.2006.21794671

Elorza, U., Harris, C., Aritzeta, A., \& Balluerka, N. (2016). The effect of management and employee perspectives of high-performance work systems on employees' discretionary behaviour. Personnel Review, 45(1), 121-141. https://doi.org/10.1108/PR-07-2014-0167

Fabi, B., Lacoursière, R., \& Raymond, L. (2015). Impact of high-performance work systems on job satisfaction, organizational commitment, and intention to quit in Canadian organizations. $\begin{array}{llll}\text { International } \quad \text { Journal } & \text { 772-790. }\end{array}$ https://doi.org/10.1108/IJM-01-2014-0005

Farmer, N. (2017). The invisible organization: How informal networks can lead organizational change. Routledge.

García, C. R., Neira, F. E., \& Varela, N. C. (2016). High-performance work systems and job satisfaction: a multilevel model. Journal of Managerial Psychology, 31(2), 451-466. https://doi.org/10.1108/JMP-04-2013-0127

George, J., \& Brief, A. (1992). Feeling good-doing good: a conceptual analysis of the mood at work-organizational spontaneity relationship, Psychological Bulletin, 112, 310-329. https://doi.org/10.1037/0033-2909.112.2.310

Graham, J. W. (1991). An essay on organizational citizenship behavior. Employee Responsibilities and Rights Journal, 4, 249-270. https://doi.org/10.1007/BF01385031

Granovetter, M. (1973). The strength of weak ties, American Journal of Sociology, 78, 1360-1380. https://doi.org/10.1086/225469

Huang, L. C., Ahlstrom, D., Lee, A. Y. P., Chen, S. Y., \& Hsieh, M. J. (2016). High performance work systems, employee well-being, and job involvement: An empirical study. Personnel Review, 45(2), 296-314. https://doi.org/10.1108/PR-09-2014-0201

Huselid, M. A. (1995). The impact of HRM practices on turnover, productivity and corporate financial performance", Academy of Management Journal, 38(3), 635-672.

Ichniowski, C., Kathryn, S., \& Giovanna, P. (1997). The Effect of Human Resource Practices on Productivity: A Study of Steel Finishing Lines, American Economic Review, 87(3), 
291-313.

Jensen, J. M., Patel, P. C., \& Messersmith, J. G. (2013). High-performance work systems and job control: Consequences for anxiety, role overload, and turnover intentions. Journal of Management, 39(6), 1699-1724. https://doi.org/10.1177/0149206311419663

Jiang, J. Y., \& Liu, C. W. (2015). High performance work systems and organizational effectiveness: The mediating role of social capital. Human Resource Management Review, 25(1), 126-137. https://doi.org/10.1016/j.hrmr.2014.09.001

Katzenbach, J. R., \& Smith, D. K. (2015). The wisdom of teams: Creating the high-performance organization. Harvard Business Review Press.

Kehoe, R. R., \& Wright, P. M. (2013). The impact of high-performance human resource practices on employees' attitudes and behaviors. Journal of management, 39(2), 366-391. https://doi.org/10.1177/0149206310365901

Li, H. Y., \& Yu, G. L. (2017). A Multilevel Examination of High-Performance Work Systems and Organizational Citizenship Behavior: A Social Exchange Theory Perspective. Eurasia Journal of Mathematics Science and Technology Education, 13(8), 5821-5835. https://doi.org/10.12973/eurasia.2017.01032a

Macduffie, J. P. (1995) Human resource bundles and manufacturing performance: Organizational logic and flexible production systems in the world auto industry", Industrial and Labor Relations Review, 48(2), 197-221. https://doi.org/10.1177/001979399504800201

Macky, K., \& Boxall, P. (2007). The relationship between 'high-performance work practices' and employee attitudes: an investigation of additive and interaction effects. The International Journal of Human Resource Management, 18(4), 537-567. https://doi.org/10.1080/09585190601178745

Macky, K., \& Boxall, P. (2008). High-involvement work processes, work intensification and employee well-being: A study of New Zealand worker experiences. Asia Pacific Journal of Human Resources, 46(1), 38-55. https://doi.org/10.1177/1038411107086542.

Nunnally, J. C. (1978). Psychometric Theory. McGraw-Hill, New York (1978).

Orbach, M., Demko, M., Doyle, J., Waber, B. N., \& Pentland, A. (2015). Sensing informal networks in organizations. American Behavioral Scientist, 59(4), 508-524. https://doi.org/10.1177/0002764214556810

Organ, D. W. (1988). Organizational Citizenship Behavior: The Soldier Syndrome. Lexington, MA: Lexington Books.

Organ, D. W. (1990). The motivational basis of organizational citizenship behavior, in L. L. Cummings \& B. M. Staw (Eds.), Research in Organizational Behavior, 12, 43-72, Greenwich, CT: JAI.

Posthuma, R. A., Campion, M. C., Masimova, M., \& Campion, M. A. (2013). A high performance work practices taxonomy: Integrating the literature and directing future research. 
Journal of Management, 39(5), 1184-1220. https://doi.org/10.1177/0149206313478184

Ramsay, H., Scholarios, D., \& Harley, B. (2000). Employees and high-performance work systems: Testing inside the black box. British Journal of industrial relations, 38(4), 501-531. https://doi.org/10.1111/1467-8543.00178

Schnake, M. (1991). Organizational citizenship: A review, proposed model, and research agenda, Human Relations, 44, 735-759. https://doi.org/10.1177/001872679104400706

Scott, J. (2017). Social Network Analysis. Sage.

Shin, D., \& Konrad, A. M. (2017). Causality between high-performance work systems and organizational performance. Journal of Management, 43(4), 973-997. https://doi.org/10.1177/0149206314544746

Sikora, D. M., Ferris, G. R., \& Van Iddekinge, C. H. (2015). Line manager implementation perceptions as a mediator of relations between high-performance work practices and employee outcomes. Journal of Applied Psychology, 100(6), 1908. https://doi.org/10.1037/ap10000024

Snape, E., \& Redman, T. (2010). HRM practices, organizational citizenship behaviour, and performance: A multi-level analysis. Journal of Management Studies, 47(7), 1219-1247. https://doi.org/10.1111/j.1467-6486.2009.00911.x

Staw, B. M., \& Boettger, R. D. (1990). Task revision: A neglected form of work performance, Academy of Management Journal, 33, 534-559.

Sun, L. Y., Aryee, S., \& Law, K. S. (2007). High-performance human resource practices, citizenship behavior, and organizational performance: A relational perspective. Academy of management Journal, 50(3), 558-577. https://doi.org/10.5465/amj.2007.25525821

Van De Voorde, K., \& Jensen, J. M. (2016). High Performance at the Expense of Employee Health? Reconciling the Dark Side of High Performance Work Systems. In Understanding the High Performance Workplace (pp. 81-102). Routledge.

Van De Voorde, K., Paauwe, J., \& Van Veldhoven, M. (2012). Employee well-being and the HRM-organizational performance relationship: a review of quantitative studies. International Journal of Management Reviews, 14(4), 391-407. https://doi.org/10.1111/j.1468-2370.2011.00322.x

Van Dyne, L., \& Cummings, L. L. (1990). Extra-role behaviors: In pursuit of construct and definitional clarity. Paper presented at the Annual Meeting of the Academy of Management, San Francisco.

Van Dyne, L. J., Graham, W., \& Dienesch, R. M. (1994). Organizational citizenship behavior: Construct redefinition, measurement, and validation, Academy of Management Journal, 37(4), 765 .

Wang, C. H., Baba, V. V., Hackett, R. D., \& Hong, Y. (2016). Effects of High-Performance Work Systems on Expanding Employee OCB Role Definitions. In Academy of Management 


\section{Macrothink}

International Journal of Human Resource Studies

ISSN 2162-3058 2018, Vol. 8, No. 3

Proceedings (Vol. 2016, No. 1, p. 12081). Briarcliff Manor, NY 10510: Academy of Management. https://doi.org/10.5465/ambpp.2016.12081abstract

Wasserman, S., \& Faust, K. (1994). Social network analysis: Methods and applications (Vol. 8). Cambridge university press. https://doi.org/10.1017/CBO9780511815478

White, M., Hill, S., McGovern, P., Mills, C., \& Smeaton, D. (2003). 'High-performance' Management Practices, Working Hours and Work-Life Balance. British journal of industrial Relations, 41(2), 175-195. https://doi.org/10.1111/1467-8543.00268

Wood, S., \& Ogbonnaya, C. (2016). High-involvement management, economic recession, well-being, and organizational performance. Journal of Management, 0149206316659111. https://doi.org/10.1177/0149206316659111

\section{Copyright Disclaimer}

Copyright for this article is retained by the author(s), with first publication rights granted to the journal.

This is an open-access article distributed under the terms and conditions of the Creative Commons Attribution license (http://creativecommons.org/licenses/by/4.0/). 